\title{
The number of families of Triatoma dimidiata in a Guatemalan house
}

\author{
Sergio Melgar/ ${ }^{+}$, Juan José Chávez, Patricia Landaverde, Franklin Herrera, \\ Antonieta Rodas, Eunice Enríquez, Patricia Dorn*, Carlota Monroy
}

\begin{abstract}
Laboratorio de Entomología Aplicada y Parasitología, Escuela de Biología, Facultad de Farmacia, Universidad de San Carlos de Guatemala, Edificio T-10, Ciudad Universitaria Zona 12, Ciudad de Guatemala, Guatemala *Loyola University New Orleans, New Orleans, US
\end{abstract}

Triatoma dimidiata is an important vector of Chagas disease in Guatemala. To help understand the biology and population dynamics of the insect, we estimated the number of full sibling families living in one house. Forty one families with an average size of 2.17 individuals were detected using random amplification of polymorphic DNA-polymerase chain reaction genetic markers. This result suggests high levels of migration of the vector, polyandry, and a significant capability for spreading the disease.

Key words: Triatoma dimidiata - polyandry - siblings

Triatoma dimidiata is a vector of great importance in the transmission of Chagas disease in Guatemala and elsewhere in Central America, due to its extensive geographical distribution and difficulties in its control. It is found in 21 of the 22 provinces of the country (Monroy et al. 2003a) with the highest house infestation indices (12-45\%) in the Eastern region. This is also the region which also has the highest prevalence of the disease (Monroy et al. 2003a).

A better understanding of the population dynamics of $T$. dimidiata is important for the formulation of control strategies against this vector aimed at decreasing infestation in human dwellings to reduce the transmission of the disease. Here we investigate the degree of kinship between individuals of $T$. dimidiata within a single house. If vectors migrate frequently between houses, the degree of kinship between individuals within one house can be expected to decrease. A high migration rate would indicate high capacity to spread the disease (Monroy et al. 2003a).

In this study the population dynamics of $T$. dimidiata was examined using random amplification of polymorphic DNA based on the polymerase chain reaction (RAPD-PCR), a technique previously shown to be useful for vector population studies (Monroy et al. 2003a). RAPD-PCR has been used to estimate the number of full-sib families of mosquitoes in oviposition sites (Apostol et al. 1993, 1994, Monroy et al. 1998), with similar results to those observed with codominant mark-

Financial support: WHO-TDR, DIGI-USAC, Netropica +Corresponding autor: melgar@wisc.edu

Received 4 August 2006

Accepted 25 January 2007 ers (Colton et al. 2003). In this study we used four primers that provided 33 loci, to determine the number of full-sib families in one house infested with T. dimidiata.

Eighty nine insects ( $T$. dimidiata) were collected in a single human dwelling located in the village El Cuje at Pueblo Nuevo Viñas, province of Santa Rosa, Guatemala (1170 m above sea level 14²14'52" N latitude, 90²8' $12^{\prime \prime}$ $\mathrm{W}$ longitude). The house was about 45 years old, made of adobe with deteriorated partial plastering and had not been fumigated. The house has dirt floor and clay tiles roof. Three adults and two children were living in the house. During the study, they used to have two or three turkeys in a nest inside the house. Most of the insects were found in cracks and crevices in the walls close to the turkeys nests. The insects were collected monthly from March 1999 to February 2000 (Table). The house was inspected monthly for one man-hour (usually $1 / 2$ hour by two people), revealing $T$. dimidiata with the age distribution shown in the Table. In addition, 40 T. dimidiata were collected from inside other houses in the village, and used as a background population for obtaining the population allele frequencies for all the loci.

DNA was extracted from insect's legs according to the method described by Coen et al. (1982) with modifications as described in Black and Munstermann (1996).

RAPD-PCR was performed with the four RAPD primers that had previously been shown to amplify triatomine DNA (Garcia et al. 1998) with slight modifications described by Calderon et al. (2004). Amplicons were electrophoresed on agarose gels, digital images obtained, and the bands scored using GeneProfiler version 4.03 (Scanalytics, Merriefield, WA). As is necessary for the dominant marker RAPD-PCR, HardyWeinberg equilibrium was assumed when calculating genotypic frequencies (Apostol et al. 1996).

We selected 33 out of 192 loci with dominant allele frequencies between 0.1013 and 0.6000 in the background population $(\mathrm{N}=40)$ using the program MCALC 2.01 (Black \& Munstermann 1996 v. 2.01) (Fig. 1). Loci with these allele frequencies were selected to obtain a threshold for discriminating among clusters of full-sib- 
TABLE

Number of adults and nymphs collected

\begin{tabular}{cccccccc}
\hline \multicolumn{7}{c}{ Stage } \\
\hline Month & $\begin{array}{c}\text { Adult } \\
+\end{array}$ & $\begin{array}{c}\text { Adult } \\
\text { đ }\end{array}$ & 2nd & 3rd & 4th & 5 th & Total \\
\hline $3 / 1999$ & 10 & 11 & & & 2 & 1 & 24 \\
$4 / 1999$ & 2 & & & & & & 2 \\
$5 / 1999$ & 1 & & & 1 & & 2 & 4 \\
$7 / 1999$ & 8 & 13 & 1 & 3 & 2 & 6 & 33 \\
$8 / 1999$ & 1 & & & & & & 1 \\
$9 / 1999$ & 2 & 2 & 1 & 2 & 6 & & 13 \\
$1 / 2000$ & 2 & 3 & & 2 & 1 & 1 & 9 \\
$2 / 2000$ & 1 & & 1 & & & & 2 \\
\hline Total & 27 & 29 & 3 & 8 & 11 & 10 & 88 \\
\hline
\end{tabular}

One individual's data is missing.

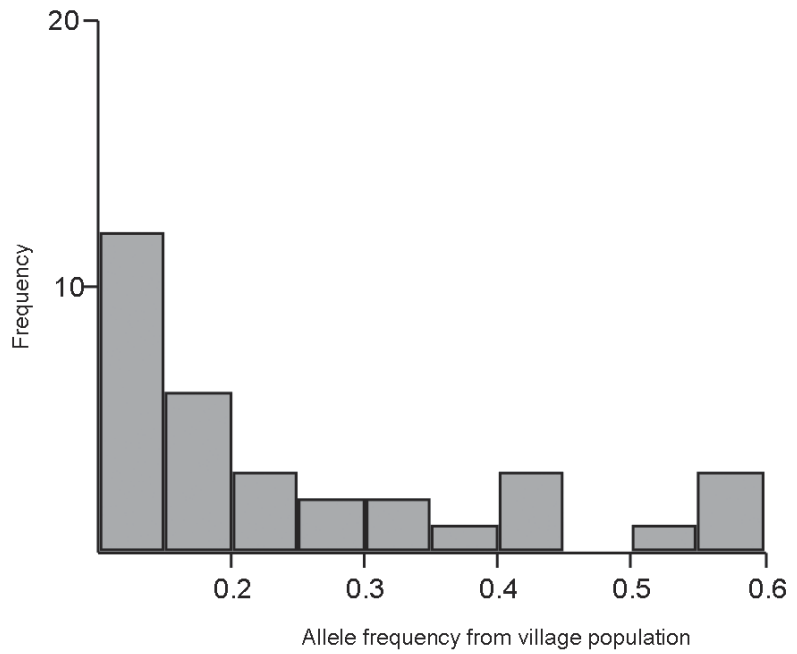

Fig. 1: distribution of the allele frequencies of the 33 selected loci calculated from 40 individuals collected in 17 surrounding houses in the village.

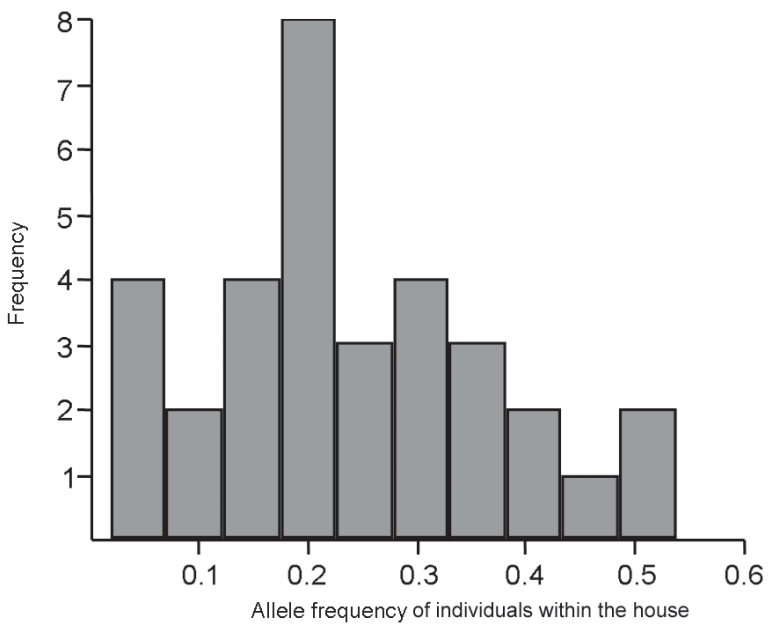

Fig. 2: distribution of the allele frequencies of the 33 selected loci calculated from 89 individuals collected in the house. lings from non-siblings (Apostol et al. 1993) (Fig. 2). The data were entered in the program Fingers 2.0 (Black \& Munstermann 1996 v. 2.0) to determine the number of existing families based on the threshold value 1-proportion match (1-M) score among unrelated individuals (0.214).

Forty one families were detected by the cluster analysis, with an average size of 2.17 members per family. Most families are represented by very few individuals. Nearly half are represented by a single individual $(46.3 \%)$ and families with two to four individuals make up an additional $48.8 \%$ (Fig. 3 ).

This is the first report of the degree of kinship of $T$. dimidiata individuals within one house. Similar studies on Aedes aegypti, using RAPD-PCR and RFLPs, show comparable results with unrelated eggs found in oviposition sites which suggests a substantial amount of migration and that females have a high capacity to spread diseases they transmit (Apostol et al. 1993, 1994, Colton et al. 2003). Results of the present study indicate that in the span of a year, members of multiple families of $T$. dimidiata coexist in the same house.

The high number of families with few members cannot be explained solely by the one year period collection time since the life cycle of the bug is relatively long, compared with those of other insects (142 \pm 64 days) (Martinez-Ibarra et al. 2001). This suggests that there are other causes such as migration which is known to occur in some populations of T. dimidiata. In Costa Rica (Zeledon et al. 2001), the Yucatan (Dumonteil et al. 2002), and Northern Guatemala (Monroy et al. 2003b) seasonal migration occurs during the dry season; however in Belize, the peak migration is during the rainy season (Petana 1971). We know that the nymphs and adults

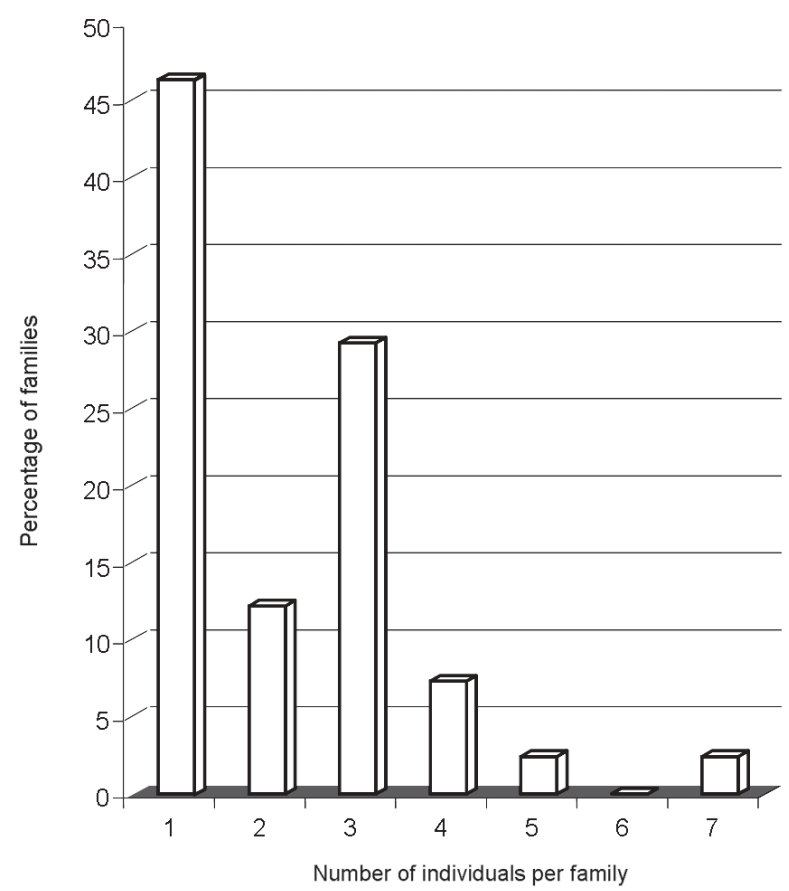

Fig. 3: frequency distribution of the family sizes of Triatoma dimidiata found in a house in a village in Jutiapa, Guatemala. 
are mobile as some bugs collected outside houses contained human blood (Zeledon et al. 2005), and some bugs collected inside houses contained wild animal blood (Sasaki et al. 2003). Migration is also evident by colonization of artificial ecotopes (Zeledon et al. 2001, Monroy et al. 2003b). High genetic similarity among populations collected in nearby Guatemalan villages was interpreted as caused by a significant amount of migration (Dorn et al. 2003).

In a previous study, migration of male individuals of $T$. dimidiata was greater than migration of females (Monroy et al. 2003b).

The high number of families represented by a single individual may be the result polyandry. In populations of $T$. dimidiata, a high degree of genetic variability has been found (Calderon et al. 2004). The population in the house seems to be old; therefore, the migration events have had the chance to accumulate more genetic diversity of the family structure through time.

The high percentage of families with a single individual suggests polyandry exists as a mating system for T. dimidiata. This would contribute to genetic variation within the populations of this vector. These results also suggest the existence of migration, which would explain the high rates of reinfestation found after fumigation of houses (Tabaru et al. 1999). Migration makes difficult the development of effective vector control strategies. Multiple approaches including house and environment improvement, fumigation, and education of the population in endemic areas will be required (Monroy et al. 1998, Zeledon \& Rojas 2006).

\section{REFERENCES}

Apostol BL, Black WC, Miller BR, Reiter P, Beaty BJ 1993. Estimation of the number of full sibling families at an oviposition site using RAPD-PCR markers: applications to the mosquito Aedes aegypti. Theor Appl Genet 86: 991-1000.

Apostol BL, Black WC, Reiter P, Miller BR 1994. Use of randomly amplified polymorphic DNA amplified by polymerase chain reaction markers to estimate the number of Aedes aegypti families at oviposition sites in San Juan, Puerto Rico. Am J Trop Med Hyg 51: 89-97.

Apostol BL, Black WC, Reiter P, Miller BR 1996. Population genetics with RAPD-PCR markers: the breeding structure of Aedes aegypti in Puerto Rico. Heredity 76: 325-334.

Black W, Munstermann L 1996. Molecular taxonomy and systematics of arthropod vectors. In BJ Beaty, W Marquardt (eds), The Biology of Disease Vectors, University Press of Colorado, Niwot, p. 438-470.

Calderon CI, Dorn PL, Melgar S, Chavez JJ, Rodas A, Rosales R, Monroy CM 2004. A preliminary assessment of genetic differentiation of Triatoma dimidiata (Hemiptera: Reduviidae) in Guatemala by random amplification of polymorphic DNA-polymerase chain reaction. J Med Entomol 41: 882887.

Coen ES, Thoday JM, Dover G 1982. Rate of turnover of structural variants in the rDNA gene family of Drosophila melanogaster. Nature 295: 564-568.

Colton YM, Chadee DD, Severson DW 2003. Natural skip oviposition of the mosquito Aedes aegypti indicated by codominant genetic markers. Med Vet Entomol 17: 195-204.
Dorn PL, Melgar S, Rouzier V, Gutierrez A, Combe C, Rosales R, Rodas A, Kott S, Salvia D, Monroy CM 2003. The Chagas vector, Triatoma dimidiata (Hemiptera: Reduviidae), is panmictic within and among adjacent villages in Guatemala. J Med Entomol 40: 436-440.

Dumonteil E, Gourbiere S, Barrera-Perez M, Rodriguez-Felix E, Ruiz-Pina H, Banos-Lopez O, Ramirez-Sierra MJ, Menu F, Rabinovich JE 2002. Geographic distribution of Triatoma dimidiata and transmission dynamics of Trypanosoma cruzi in the Yucatan peninsula of Mexico. Am J Trop Med Hyg 67: 176-183.

Garcia AL, Carrasco HJ, Schofield CJ, Stothard JR, Frame IA, Valente SA, Miles MA 1998. Random amplification of polymorphic DNA as a tool for taxonomic studies of triatomine bugs (Hemiptera: Reduviidae). J Med Entomol 35: 38-45.

Martinez-Ibarra JA, Barcenas-Ortega NM, Nogueda-Torres B, Alejandre-Aguilar R, Lino Rodriguez M, Magallon-Gastelum E, Lopez-Martinez V, Romero-Napoles J 2001. Role of two Triatoma (Hemiptera: Reduviidae: Triatominae) species in the transmission of Trypanosoma cruzi (Kinetoplastida: Trypanosomatidae) to man in the west coast of Mexico. Mem Inst Oswaldo Cruz, 96: 141-144.

Monroy C, Rodas A, Mejia M, Tabaru Y 1998. Wall plastering and paints as methods to control vectors of Chagas disease in Guatemala. Med Entomol Zool 49: 187-193.

Monroy C, Rodas A, Mejia M, Rosales R, Tabaru Y 2003a. Epidemiology of Chagas disease in Guatemala: Infection rate of Triatoma dimidiata, Triatoma nitida and Rhodnius prolixus (Hemiptera, Reduviidae) with Trypanosoma cruzi and Trypanosoma rangeli (Kinetoplastida, Trypanosomatidae). Mem Inst Oswaldo Cruz 98: 305-310.

Monroy MC, Bustamante DM, Rodas AG, Enriquez ME, Rosales RG 2003b. Habitats, dispersion and invasion of sylvatic Triatoma dimidiata (Hemiptera: Reduviidae: Triatominae) in Peten, Guatemala. J Med Entomol 40: 800-806.

Petana WB 1971. American trypanosomiasis in British Honduras. X. Natural habitats and ecology of Triatoma dimidiata (Hemiptera, Reduviidae) in the El Cayo and Toledo districts, and the prevalence of infection with Trypanosoma (Schizotrypanum) cruzi in the wild-caught bugs. Ann Trop Med Parasitol 65: 169-178.

Sasaki H, Rosales R, Tabaru Y 2003. Host feeding profiles of Rhodnius prolixus and Triatoma dimidiata in Guatemala (Hemiptera: Reduviidae: Triatominae). Med Entomol Zool 54: 283-289.

Tabaru Y, Monroy C, Rodas A, Mejia M, Rosales R 1999. The geographical distribution of vectors of Chagas disease and populations at risk of infection in Guatemala. Med Entomol Zool 50: 9-17.

Zeledon R, Rojas JC 2006. Environmental management for the control of Triatoma dimidiata (Latreille, 1811) (Hemiptera: Reduviidae) in Costa Rica: a pilot project. Mem Inst Oswaldo Cruz 101: 379-86.

Zeledon R, Calvo N, Montenegro VM, Lorosa ES, Arevalo C 2005. A survey on Triatoma dimidiata in an urban area of the province of Heredia, Costa Rica. Mem Inst Oswaldo Cruz 100: 507-512.

Zeledon R, Montenegro VM, Zeledon O 2001. Evidence of colonization of man-made ecotopes by Triatoma dimidiata (Latreille, 1811) in Costa Rica. Mem Inst Oswaldo Cruz 96: 659-660. 